\title{
Expanding ESL Students' Vocabulary Through TikTok Videos
}

\author{
Audrey A. Bernard Ining, \\ Kolej Vokasional Keningau, \\ Beg Berkunci No. 4, Jalan Bariawa Ulu Keningau, 89009 Keningau, Sabah, \\ Malaysia. \\ audyvaleria@gmail.com
}

Article History: Submitted on $2^{\text {nd }}$ April 2021 ; Accepted on 14 ${ }^{\text {th }}$ August 2021; Published on 30th December 2021

\begin{abstract}
TikTok is a video-sharing social network that has abruptly gained popularity for the past few years due to its unique feature of short-form videos on various genres particularly comedy and performance. The videos produced from this platform have been used widely in multiple contexts including classroom teaching. Thus, this project delved into the role of TikTok in capturing students' attention and introducing them to new vocabulary during English language class through some selected videos from the app. Most students could barely pay attention to their teachers during physical classes or online lessons. This could possibly hinder them from participating actively in classroom activities. Due to the nature of TikTok videos that are shorter in duration with humorous yet informative content, these videos might serve as engaging teaching materials. The results showed that the students displayed improved level of attention, interest and understanding of the subject matter that was being taught in class through TikTok videos. It is recommended that more studies should be done to analyze the multiple types and genres of TikTok videos and how these variables influence students' learning.
\end{abstract}

Keywords: Tiktok, vocabulary learning, digital learning.

\section{INTRODUCTION}

TikTok, an application founded in 2016 in China, which Chinese pattern named Douyin, is a platform for making and sharing short videos, which has then became one of the fastest growing social networks in the world. As of January 2020, TikTok has reached more than 150 countries worldwide, with more than 400 million daily active users (Sensor, 2020). TikTok allows users to create interesting videos of various content with its 
easy to use special effects and editing tools, producing videos from a range of 3 to 90 seconds, and has features which enable users to interact with their audience through its comments and private chats section (Demmy and Fathul, 2018).

There are many reasons why TikTok has been steadily increasing in its popularity, particularly among the younger generation. TikTok has a young user base which made up of $69 \%$ of the users aged from 16 to 24 (Sloane and Rittenhouse, 2019). Majority of its users are of the Generation Z, in which they are claimed to be highly educated, tech-savvy by nature, prefers graphics, enjoys creating content and they are the generation who are constantly connected to their mobile screen (Fromm and Read, 2018; Prioparas et al., 2017; Smith, 2019). Besides, TikTok videos are also shorter in duration, hence they are able to capture better interest and the short attention span for many learners. Learning in the form of shorter video will significantly encourage learners to take part in task-relevant activities and reduce task-irrelevant activities (Szpunar et. al, 2013).

Besides that, TikTok is also known for its colorful, engaging and its variety of content which brings many benefits for its audience. The categories of shared knowledge on TikTok vary from creative skills and personal experience to explicit knowledge such as science, technology, and culture (CBNData, 2017). Su (2018) determined that users display positive attitude on TikTok as they are able to learn many skills that are beneficial in their daily lives. TikTok also acts as a good facilitator for the delivery of teaching materials to students. Educational video media that are included in the videos are contents that have been designed for learning, hence the content has been adapted to the learning objectives to facilitate students in their learning (Erniasih, 2018). Many teachers have been using the platform to develop their own clips to illustrate complicated concepts, to explain rules or theories, or simply to share specific task instructions. These videos are downloadable and shareable. Hence, students will benefit a lot from this process, as they have unrestricted access to the content and points shared in the videos.

Vocabulary is the foundation of acquiring a second language. Without learning vocabulary, communication in the second language becomes difficult (Rohmatillah, 2014). Vocabulary is defined as a language element that links the four language skills in learning a foreign language, which include listening, speaking, reading and writing (Huyen and Nga, 2003). Thornbury (2006) stated that in order to master vocabulary, students are required to have comprehensive knowledge about vocabularies. These knowledge include understanding the meanings, its spoken and written form, the grammatical behaviour, the word derivation, its collocations, the register of the words (both spoken and written), the connotations or associations as well as the frequency of the words. Cahyono and Widiati (2008) stated that the purpose of vocabulary teaching is to enable learners to understand the concept of unfamiliar words, to acquire greater number of words, as well as to apply and utilize those words successfully for communicative purposes. Whereas, 
Intaraprasert (2004) outlined that the main objectives of vocabulary learning are to discover the meanings of new words, to retain the knowledge of newlylearned words, and to expand the knowledge of English vocabulary. Therefore, in order to influence positive vocabulary growth among students, effective strategies both in teaching and learning are required.

In this preliminary study, the researcher used selected and filtered TikTok videos to expand ESL students' vocabulary. In choosing the right videos for vocabulary learning, the students' learning needs, interests, characteristics, experience and developmental maturity are put into consideration. The main purpose of the study is to expand the vocabulary knowledge of the English as Second Language (ESL) learners as vocabulary learning is essential to the English language teaching. Most of the ESL learners in Malaysia face learning challenges to acquire and comprehend lexical items, mainly because they are lacking in vocabulary (Naginder Kaur, 2013). Alqahtani (2015) argued that having low vocabulary knowledge creates severe problems to learners, which ultimately impedes their learning of English language. Hence, many of these students fail to understand others, or express their thoughts and ideas in both verbal and written form. This is particularly evident during lessons, where students faced difficulties to present and write in English. They were unable to express their thoughts by connecting the ideas, and hence resulted in repetitive and redundant use of English words throughout their presentation and writing.

In order to expand the students' vocabulary knowledge, the TikTok videos are used by following the framework from Michael Greeves (2006), which included four approaches; (i) to provide rich and varied language experiences; (ii) to teach individual words, (iii) to teach word-learning strategies, and (iv) to foster word consciousness. In the study, the TikTok videos are introduced in the first phase, where they are used to deliver the selected vocabulary for the students to learn. In the second phase, the words will then be taught individually by providing students with sufficient information related to the words. The third phase is to teach students the strategies on how to infer the meaning of unknown words through making sense of the context or the surrounding words or sentences of the unfamiliar word. The last phase, also the most important, is to develop word consciousness within the students and maintain their interest in words through further writing.

Research on the application of social media in language classrooms of recent years has shown significant findings in enhancing the learning experience for language students. However, studies on the impact of TikTok videos towards vocabulary teaching and learning are very limited. In Malaysia, a study on the use of TikTok as a tool in enhancing ESL writing skill was conducted in 2018 by a group of researchers led by Kamini Karthigesu. In the study, TikTok videos were used to teach students about action verbs, in which their learning of these verbs will help in strengthening their writing skills. The selected action verbs were categorized into topics. Students' 
creativity was also promoted as they produced their own shareable learning materials which helped to expose them to real life learning and networking. Findings from the study concluded that the students' scores from the three different schools increased respectively from their pre to post-test. It was also concluded that the intervention has lowered participants' anxiety and enhanced their motivation towards learning English.

In Russia, TikTok videos were used in the field of studying Russian as a foreign language. The findings from the study conducted by Si (2020) found that short videos allow one to concentrate attention, have a bright emotional specter, have better memorization of new vocabulary, uses correct intonation and pronunciation, as well as giving better visual video examples for the use of new vocabulary. Hence, it can be concluded that TikTok is an effective tool in teaching foreigners Russian vocabulary and Russian speech. Despite all of the positive results, the use of TikTok has also somewhat fell short. Findings stated that the content quality of each short videos is different and fragmented, which could still not replace the main teaching method. A similar study on TikTok was also recently conducted in Indonesia by Syaifuddin et. al. (2021), in which, the results of the study demonstrated that the use of TikTok in writing descriptive text fostered a positive learning environment within the students. Students were seen actively participating in their lessons as they become more motivated in their learning.

Therefore, the primary aim of this study is to investigate the further impact of TikTok videos in expanding ESL students' vocabulary learning. The study sought to answer the following questions: (1) How do TikTok videos help in expanding ESL students' vocabulary learning? (2) What are the ESL students' perceptions of using TikTok videos in learning vocabulary?

\section{METHOD}

The research aims to share the preliminary findings on the impact of using TikTok videos to further enhance ESL students' vocabulary learning, precisely on the ways of how it can help and to investigate on the students' perceptions of using TikTok in learning. Among the criteria that were considered before selecting suitable 'TikTok videos for the students' vocabulary learning: i) the relevance and connection of the video content towards the topic of study at the time; ii) students' familiarity of the vocabulary used, and iii) the contextualization of the selected videos for better comprehension. The videos were implemented in the introductory stage of vocabulary learning where topic of the day was introduced to the students. The videos were also used as the attention grabber to engage and attract students' interest. The words and content in the videos were then thoroughly explained and discussed by the researcher during lessons.

In the reinforcement stage, students were given guided practice on how to use the newly-learned words from TikTok to real-life daily conversations and by constructing simple sentences to check on their understanding. Lastly, in the final stage of learning, students were required to 
apply and practice the new words or phrases with their classmates through short presentation and essay writing.

This study employed a qualitative methodology by conducting focus group interview sessions with the eight selected participants. The participants for the preliminary study were students from Kolej Vokasional Keningau, taking Early Childhood Education course. Participants were selected through purposive sampling, in which, in this type of non-random sampling, researcher identified and selected participants that are adept and wellinformed with the phenomenon of interest of the study (Creswell and Clark, 2011). In this study, the selected participants are similar in age, share the same background and cultures, they are of the generation who is well up-to-date to TikTok, and have similar language proficiency. They were also easily available to the researcher and were willing to contribute and participate in the study.

An interview is defined as a conversation in which its aim is to collect data and further descriptions from an interviewee, with respect to the interpretation of the meanings of the described phenomena (Kvale, 1994). The type of interview selected was the semi-structured interview, with openended questions. Rubin and Rubin (2005) described that this type of interview is more flexible than the structured interview as it permits depth to be achieved by providing opportunities for the interviewer to probe and expand the interviewees' responses. The interviews were carried out after the implementation of TikTok videos in classroom teaching for vocabulary learning. Findings gathered from the interview sessions will be analyzed by using thematic analysis approach. Thematic analysis is a method of identifying, analyzing and reporting similar patterns or themes within data (Braun and Clarke, 2006). The raw data from the interview will be coded and extracted into relevant themes.

\section{FINDINGS AND DISCUSSION}

In order to answer the research questions, the interview data was transcribed, coded and categorized into three different themes based on the patterns; (i) content, (ii) features, and (iii) authenticity. Findings from the preliminary study demonstrated that TikTok helps in expanding the vocabulary learning of ESL students as it introduces learners to specific terms and phrases through its diverse topics and themes; it provides more options for learners to access the language through its multiple features, and it helps in familiarizing learners with different sets of vocabulary through its real-life content. 
Table 1:

Findings on The Impact of Using TikTok Videos In Expanding Students' Vocabulary Learning

\begin{tabular}{|c|c|c|c|}
\hline No & Responses & Category & Theme \\
\hline 1 & $\begin{array}{l}\text { "For me, I use TikTok to watch cooking } \\
\text { videos. Some of the video creators put } \\
\text { captions in their videos. By learning } \\
\text { vocabulary from cooking TikTok videos, it } \\
\text { belps you to communicate better when you } \\
\text { talk about cooking with your friends." }\end{array}$ & \multirow[t]{3}{*}{$\begin{array}{l}\text { Students learned } \\
\text { new words by } \\
\text { browsing content } \\
\text { which fit to their } \\
\text { interests. }\end{array}$} & \multirow[t]{6}{*}{$\begin{array}{l}\text { Content } \\
\text { of the } \\
\text { videos }\end{array}$} \\
\hline 2 & $\begin{array}{l}\text { "How the content creator create their } \\
\text { content and what kind of language or words } \\
\text { they use in their content." }\end{array}$ & & \\
\hline 3 & $\begin{array}{l}\text { "We browse through the videos based on our } \\
\text { interest for example, videos about makeup. } \\
\text { We will learn more vocabulary from the } \\
\text { videos and eventually we will apply the same } \\
\text { vocabulary in making our own TikTok } \\
\text { videos or even in our daily conversations } \\
\text { with friends." }\end{array}$ & & \\
\hline 4 & $\begin{array}{l}\text { "There are so many interesting, fun, } \\
\text { educational videos on TikTok. To search } \\
\text { for videos of learning material on TikTok, } \\
\text { students should use the \#teachersoftiktok. } \\
\text { Most teachers who use this hashtag are } \\
\text { teachers who are fluent in English. } \\
\text { Therefore, students can learn about a school } \\
\text { subject and communicate in English at the } \\
\text { same time." }\end{array}$ & \multirow[t]{3}{*}{$\begin{array}{l}\text { Students can find } \\
\text { various content } \\
\text { created by } \\
\text { multiple content } \\
\text { creators and } \\
\text { learned many } \\
\text { new words } \\
\text { through the use } \\
\text { of hashtags in } \\
\text { TikTok. }\end{array}$} & \\
\hline 5 & $\begin{array}{l}\text { "Tiktok is an app that is used by people } \\
\text { around the world. There are a lots of } \\
\text { English teachers that teaching English with } \\
\text { different techniques and they make it more } \\
\text { interesting." }\end{array}$ & & \\
\hline 6 & $\begin{array}{l}\text { "We have TikTok Guru on TikTok so } \\
\text { students can gain more knowledge through } \\
\text { their content." }\end{array}$ & & \\
\hline 7 & $\begin{array}{l}\text { "TikTok creator sometimes provide a } \\
\text { subtitle so I think I can use subtitle to watch } \\
\text { it... with subtitle I think it helps me a lot." }\end{array}$ & $\begin{array}{l}\text { Students learned } \\
\text { new words } \\
\text { through the use } \\
\text { of subtitles. }\end{array}$ & $\begin{array}{l}\text { Features } \\
\text { of the } \\
\text { videos }\end{array}$ \\
\hline
\end{tabular}




\begin{tabular}{|c|c|c|}
\hline 8 & $\begin{array}{l}\text { "I am not familiar with a few of the advance } \\
\text { words until I watch the TikTok videos } \\
\text { given to me. The videos belped to raise my } \\
\text { level of vocabulary to construct much more } \\
\text { better sentences in any upcoming exam. It is } \\
\text { because their video presentation is short and } \\
\text { simple yet understandable and effective." }\end{array}$ & $\begin{array}{l}\text { TikTok videos } \\
\text { are short, simple, } \\
\text { and easy to } \\
\text { understand. }\end{array}$ \\
\hline 9 & $\begin{array}{l}\text { "Through the way the video is made is not } \\
\text { boring, short, interesting and clear." }\end{array}$ & \\
\hline 10 & $\begin{array}{l}\text { "When there are catchy unfamiliar words, I } \\
\text { usually will look up for the meaning } \\
\text { immediately." }\end{array}$ & \multirow{2}{*}{$\begin{array}{l}\text { Students learned } \\
\text { and retained } \\
\text { newly-learned } \\
\text { words by pausing } \\
\text { and repeating the } \\
\text { TikTok videos. }\end{array}$} \\
\hline 11 & $\begin{array}{l}\text { "The videos features a variety of new words, } \\
\text { from there I can add to my vocabulary and } \\
\text { I can remember them every time I watch the } \\
\text { videos." }\end{array}$ & \\
\hline 12 & $\begin{array}{l}\text { "I can access TikTok better because it } \\
\text { doesn't use beavy Internet data like Google } \\
\text { Classroom or Telegram." }\end{array}$ & $\begin{array}{c}\text { Students } \\
\text { preferred } \\
\text { learning through } \\
\text { TikTok as it } \\
\text { doesn't consume } \\
\text { much Internet } \\
\text { data. }\end{array}$ \\
\hline 13 & $\begin{array}{l}\text { "I really love the 'save' and 'share' function. } \\
\text { I can watch and use the videos that I've } \\
\text { saved. I can also watch the saved videos } \\
\text { repeatedly and share them with my friends." }\end{array}$ & $\begin{array}{l}\text { Students learned } \\
\text { new words by } \\
\text { downloading the } \\
\text { videos and } \\
\text { watching them } \\
\text { repeatedly. }\end{array}$ \\
\hline 14 & $\begin{array}{l}\text { "I like TikTok better than reading slides. } \\
\text { There are less words and more graphics, } \\
\text { which help me to focus more in learning." }\end{array}$ & $\begin{array}{l}\text { Students learned } \\
\text { better through } \\
\text { TikTok as they } \\
\text { provide more } \\
\text { graphics and less } \\
\text { wordy than } \\
\text { traditional } \\
\text { teaching } \\
\text { materials. }\end{array}$ \\
\hline 15 & $\begin{array}{l}\text { "The vocabulary from the TikTok videos } \\
\text { are very helpful and comes in handy for } \\
\text { future English exam and when I am } \\
\text { speaking to any English lecturers at the } \\
\text { college as well as if I ever get the chance to } \\
\text { visit foreign places. It is so because the words }\end{array}$ & $\begin{array}{l}\text { Students learned } \\
\text { new words and } \\
\text { improved their } \\
\text { pronunciation } \\
\text { through the } \\
\text { language used by }\end{array}$ \\
\hline
\end{tabular}




\begin{tabular}{|c|c|c|c|}
\hline & $\begin{array}{l}\text { from the videos are advance and it help me } \\
\text { a lot to communicate confidently." }\end{array}$ & $\begin{array}{l}\text { native English } \\
\text { speakers. }\end{array}$ & \\
\hline 16 & $\begin{array}{l}\text { "Watching videos created by native English } \\
\text { speakers belps me a lot in improving my } \\
\text { pronunciation." }\end{array}$ & \multirow{2}{*}{$\begin{array}{l}\text { Students enjoyed } \\
\text { learning various } \\
\text { English accents } \\
\text { used } \\
\text { internationally. }\end{array}$} & \multirow{4}{*}{$\begin{array}{l}\text { Authentici } \\
\text { ty of the } \\
\text { videos }\end{array}$} \\
\hline 17 & $\begin{array}{l}\text { "We can learn various type of English } \\
\text { accent since TikTok is popular all over the } \\
\text { world." }\end{array}$ & & \\
\hline 18 & $\begin{array}{l}\text { "For me, I use TikTok to showcase my } \\
\text { dancing talent. From TikTok, I've met } \\
\text { many new friends from all around the world } \\
\text { who also like to dance. We usually } \\
\text { communicate in English." }\end{array}$ & $\begin{array}{c}\text { Students used } \\
\text { TikTok to } \\
\text { showcase talents } \\
\text { and } \\
\text { communicate } \\
\text { with friends from } \\
\text { other countries } \\
\text { by using English. }\end{array}$ & \\
\hline 19 & $\begin{array}{l}\text { "There's this one video that I've watched, } \\
\text { which belped me a lot in improving my } \\
\text { ability to introduce myself in a social setting. } \\
\text { I am able to use those phrases that I've } \\
\text { learned from TikTok in real-life } \\
\text { situation." }\end{array}$ & $\begin{array}{l}\text { Students learned } \\
\text { new phrases } \\
\text { from TikTok and } \\
\text { were able to use } \\
\text { them in real-life } \\
\text { situations. }\end{array}$ & \\
\hline
\end{tabular}

Table 2:

Findings on The Students' Perceptions of Using TikTok Videos For Vocabulary Learning

\begin{tabular}{|c|l|}
\hline No & \multicolumn{1}{|c|}{ Responses } \\
\hline 1 & "It's a great tool for learning if we know how to use it wisely." \\
\hline 2 & $\begin{array}{l}\text { "TikTok, is overall an enjoyable and educational app at the same time. } \\
\text { However, we should be a better user and avoid from making thirst-trap } \\
\text { contents." }\end{array}$ \\
\hline 3 & $\begin{array}{l}\text { "Everyone love to use TikTok nowadays and it's fun, teachers can use } \\
\text { tiktok as another place to give their lesson. For example, create content } \\
\text { using TikTok trend about education." }\end{array}$ \\
\hline 4 & $\begin{array}{l}\text { "Teachers and lecturers play an important role in encouraging students to } \\
\text { use the TikTok application as a learning material. Teachers can enhance }\end{array}$ \\
\hline
\end{tabular}




\begin{tabular}{|c|l|}
\hline & $\begin{array}{l}\text { students' creative thinking by making videos about them speaking in } \\
\text { English too. We must move in line with the increasingly modern era." }\end{array}$ \\
\hline 5 & $\begin{array}{l}\text { 'T think. TikTok can help me focus in my learning but maybe just } 50 \% \text { in } \\
\text { terms of what I can learn and understand from the video. I would still need } \\
\text { help from the teachers in order to learn better." }\end{array}$ \\
\hline
\end{tabular}

\section{TikTok Introduced Learners to Specific Terms and Phrases Through Its Diverse Topics and Themes}

The findings showed that TikTok helped in expanding ESL students vocabulary by introducing learners to specific terms and phrases through the diverse topics and themes of videos created in the platform. Students became more engaged in their learning as TikTok provided multiple supply of videos with interesting, diversified contents of various genres, ranging from humorous, religious to educational videos. For example, a student expressed that she liked learning new recipes from TikTok. These videos are easily searchable on TikTok by browsing hashtags related to the content. By watching those videos, she stated that she managed to pick up various new vocabulary from the ingredients and cooking tools displayed in the videos. The diversified content of the topics found in TikTok has helped students in expanding their vocabulary knowledge as they are given exposures to various new, unfamiliar words in different contexts. Baumann et al., (2003) and Graves (2000) found that one of the indirect methods of teaching vocabulary includes providing multiple exposures to words in various contexts. In the findings, students concluded that they did not only learn new words or phrases from the videos, but they have also become more aware of the various global and social issues around the world. These new words are particularly useful in expanding their vocabulary to enhance their speaking and writing skills.

\section{Tik'Tok Offered More Options For Learners To Access The Language Through Its Multiple Features}

The findings also demonstrated that students were able to expand their vocabulary as TikTok provided ample opportunities for them to access the language through its multiple features. In terms of the TikTok features, students stated that they have learned multiple new words through the use of captions and subtitles provided in the videos. From these captions and subtitles, students were also able to learn the correct enunciation and pronunciation of some unfamiliar words. Al Seghayer (2001) stated that students' rate of attention in learning is higher, and they learn better when visuals are added to vocabulary instruction. Traore and Kyei- Blankson (2011) also stated that students improved their learning through the simultaneous use of audio and visual presentations as they are able to listen 
to the vocabulary words while being visually stimulated by the graphics and pictures used. In the interview, a student stated that whenever she came across a new word from TikTok, she would resort to dictionary in order to find the meaning of the particular word. Another student also stated that TikTok enhanced her communication and presentation skills, as they learned various new phrases from the subtitles provided in TikTok. Thus, she became more confident when speaking in English in front of her classmates. One feature that was particularly reviewed positively from the students, is the 'save' and 'share' function. Majority of the students enjoyed sharing their favorite TikTok videos to other social media sites. Some of them resort to saving their favorite videos so they can watch the videos repeatedly. The repetitive watching of those videos has helped them tremendously in their vocabulary learning, particularly in improving their pronunciation skills. Silverman and Hines (2009) stated that repeated viewings of video are significant for vocabulary learning. All 8 of the students also liked the fact that the videos are short, simple, but efficient. Since most TikTok videos are short in duration, the videos are easily accessible to them as the platform do not require heavy use of Internet data.

\section{TikTok Familiarized Learners With Different Sets of Vocabulary Through Its Authentic Content}

It is also found that TikTok helped in improving the students vocabulary as it familiarizes students with different sets of vocabulary through its authentic and real-life content. Majority of the students enjoyed watching TikTok as the platform exposed them to many educational content creators around the world, that provided them with authentic learning materials and displayed different new techniques of learning for various subjects. Morrow (1977) defined authenticity as a stretch of real language, produced by a real speaker or writer for a real audience, designated to deliver a real message. Schiffrin (1996) stated that authentic materials, specifically audio-visual ones, provides richer source of input for learners and they can be exploited in different ways and on different levels in order to expand learners' communicative competence. Ktoridou, Yiangou and Zarpetea (2002) found that by using videos to enhance students' vocabulary recognition and comprehension, it helps to provide language learners the exposure to authentic content and context, in which learners can significantly improve their language skills. By watching videos produced from a variety of English speakers across the nation, the students were able to learn and to mimic different accents. Ultimately, this helped students to enunciate and pronounce words better as they get to listen to how native speakers communicate. The platform also provided opportunities for students to build networks and meeting new friends from different countries through the comment or direct messages section. One student 
mentioned that she enjoyed using TikTok, as the platform helped her a lot in improving her English as she learned many new vocabularies and conversational phrases by exchanging comments and messages with her Internet friends.

\section{TikTok Promoted Positive Learning Environment for Learners}

The findings also showed that TikTok promoted and created a positive learning environment for the ESL students. Overall, the students displayed positive attitude, increased motivation and acceptance in using TikTok videos to expand their vocabulary learning. When interviewed, all 8 of the students stated that they own TikTok accounts, and are frequent users of TikTok as they spent around 5 to 8 hours in a day browsing and watching TikTok videos. A notable finding in the initial phase was although these students are frequent users, half of them admitted to watching TikTok for mainly entertainment purposes. Thus, when they were exposed to such educational videos, they found that TikTok is indeed a useful tool for learning. They mentioned that using TikTok created a fun learning environment for students as lessons became more enjoyable than traditional teaching methods. However, majority of the students agreed that TikTok could not serve as a stand-alone teaching material, as they would still need proper guidance from their teachers. Hence, TikTok should act only as a supplement in the teaching and learning process. This finding is similar to the results of the research done by Kamil et. al. (2000), and Verhallen and Bus (2010), who stated that although using videos offer more multifaceted nonverbal support than books, but watching videos alone does not sufficiently support word learning and that instruction on word meanings is still required.

\section{CONCLUSION}

Results of the preliminary research indicated that the use of TikTok contributed positively to expanding ESL students' vocabulary learning. Students learned many new vocabulary through various content found in TikTok, its useful and handy features which provides sufficient audio, graphics, subtitles and its 'save function, as well as through the authenticity of the videos. Since TikTok is the current trend nowadays, using the platform can be a good alternative for teachers to apply the method in their teaching, provided that the selected videos from TikTok are suitable for the students' level, interest, and best to match their learning needs and styles. This study would also suggest teachers who would like to use TikTok as their teaching tool to create their own videos with their own designated content and topics that matched their syllabus, in order to provide a better and more authentic learning experiences for their own students. Self-made videos by teachers could also help in better understanding of the students ${ }^{6}$ needs and learning styles. 
In the future, a more extensive research and further analysis should be carried out to study the different types of genres and how these genres would affect students motivation in learning.

\section{REFERENCES}

Alqahtani, M. (2015). The importance of vocabulary in language learning and how to be taught. International journal of teaching and education, 3(3), 2134.

Al Seghayer, K. (2001). The effect of multimedia annotation modes on L2 vocabulary acquisition: A comparative study. Language Learning \& Technology, 5(1), 202-232.

Baumann, J. F., Kame'enui, E. J., \& Ash, G. E. (2003). Research on vocabulary instruction: Voltaire redux. Handbook of research on teaching the English language arts, 2(1), 752-785.

Braun, V., \& Clarke, V. (2006). Using thematic analysis in psychology.Qualitative Research in Psychology, 3(2), 77 101. https://doi.org/10.1191/1478088706qp063oa

Cahyono, B. Y., \& Widiati, U. (2008). Teaching of EFL Vocabulary in the Indonesia Context: The State of The Art. TEFLIN Journal, 19 (1), 117.

CBNdata. (2017). 2017 duanshipin hangye dashuju dongcha [The insights of short video industries in 2017], 2017. Retrieved from https://cbndata.com/report $/ 397 /$ detail ?isReading $=$ report\&page $=1$

Creswell, J. W., \& Clark, V. P. (2011). Designing and conducting mixed methods research. Sage Publications. Thousand Oaks: USA.

Deriyanto, D., \& Qorib, F. (2019). Persepsi Mahasiswa Universitas Tribhuwana Tunggadewi Malang terhadap Penggunaan Aplikasi Tik Tok. JISIP: Jurnal Ilmu Sosial Dan Ilmu Politik, 7(2).

Erniasih, U., Pramono, S., \& Atno, A. (2018). Perbedaan Hasil Belajar dengan Menggunakan Media Video Edukasi dan Media Video Dokumenter pada Pembelajaran Sejarah di SMA N 12 Semarang Tahun Ajarah 2017/2018. Indonesian Journal of History Education, 6(2), 162-171. Retrieved from https://journal.unnes.ac.id/sju/index.php/ijhe/article/view/27646

Fromm, J., \& Read, A. (2018). Marketing to Gen Z: The rules for reaching this vast-and very different-generation of influencers. Amacom.

Graves, M. F. (2000). A vocabulary program to complement and bolster a middle-grade comprehension program. Reading for meaning: Fostering comprehension in the middle grades, 116-135.

Green, J., Willis, K., Hughes, E., Small, R., Welch, N., Gibbs, L., \& Daly, J. (2007). Generating best evidence from qualitative research: the role of data analysis. Australian and New Zealand journal of public health, 31(6), 545-550. 
Kamil, M. L., Intrator, S. M., \& Kim, H. S. (2000). The effects of other technologies on literacy and literacy learning (Vol. III)(M. Kamil. R. Barr, P. Mosenthal, \& P. Pearson, Eds.).

Ktoridou, D., Zarpetea, P., \& Yiangou, E. (2002). Integrating technology in EFL. In VII Conference of Pedagogiki Eteria of the University of Cyprus (pp. 437-407).

Kvale, S. (1994). Interviews: An introduction to qualitative research interviewing. Sage Publications, Inc.

Morrow, K. (1977). Authentic texts and ESP. In Holden, S. (ed.). English for specific purposes. Modern English Publications.

Graves, M. F. (2000). A Vocabulary Program to Complement and Bolster Comprehension Program. Reading for meaning: Fostering comprehension in the middle grades, 116.

Graves, M. F. (2016). The vocabulary book: Learning and instruction. Teachers College Press.

Huyen, N. T. T., \& Nga, K. T. T. (2003). Learning vocabulary through games. Asian EFL Journal, 5(4), 90-105.

Intaraprasert, C. (2004). EST students and vocabulary learning strategies: A preliminary investigation. Unpublished Research, Suranaree University of Technology, Nakhon Ratchasima, Thailand.

Kaur, N. (2013). The need for autonomous vocabulary learners in the Malaysian ESL classroom. GEMA Online ${ }^{\circledR}$ Journal of Language Studies, 13(3).

Priporas, C. V., Stylos, N., \& Fotiadis, A. K. (2017). Generation Z consumers' expectations of interactions in smart retailing: A future agenda. Computers in Human Behavior, 77, 374-381.

Rohmatillah, R. (2014). A STUDY ON STUDENTS'DIFFICULTIES IN LEARNING VOCABULARY. English Education: jurnal tadris bahasa Inggris, 6(1), 75-93.

Rubin, H. J., \& Rubin, I. S. (2011). Qualitative interviewing: The art of hearing data. sage.

Si, X. (2020). Short Video-a New Approach to Language International Education. Communication trends in the post-literacy era: polylingualism, multimodality and multiculturalism as prerequisites for new creativity.Ekaterinburg, 2020, 121-129.

Silverman, R., \& Hines, S. (2009). The effects of multimedia-enhanced instruction on the vocabulary of English-language learners and nonEnglish-language learners in pre-kindergarten through second grade. Journal of educational psychology, 101(2), 305.

Sloane, G., \& Rittenhouse, L. (2019). FIRST LOOK AT TIKTOK'S GAME PLAN: Leaked pitch deck reveals how the app is luring brands. Spoiler alert: there will be gummy bears. Advertising Age, 90(20), 6 . https://search.proquest.com/docview/2306286732?rfr_id=info $\% 3$ Axri $\% 2$ Fsid $\% 3$ Aprimo.

Smith, K. T. (2019). Mobile advertising to Digital Natives: preferences on 
content, style, personalization, and functionality. Journal of Strategic Marketing, 27(1), 67-80.

$\mathrm{Su}$, Y. C. (2007). Students' changing views and the integrated-skills approach in Taiwan's EFL college classes. Asia Pacific Education Review, 8(1), $27-$ 40.

Szpunar, K. K., Khan, N. Y., \& Schacter, D. L. (2013). Interpolated memory tests reduce mind wandering and improve learning of online lectures. Proceedings of the National Academy of Sciences, 110(16), 63136317.

Thornbury, S. (2006). How to teach vocabulary. Pearson Education India.

Traore, M., \& Kyei-Blankson, L. (2011). Using literature and multiple technologies in ESL instruction. Journal of Language Teaching \& Research, 2(3).

Tower, S. (2020). TikTok crosses 2 billion downloads after best quarter for any app ever. Recuperado de https://sensortower. com/blog/tiktokdownloads-2-billion.

Verhallen, M. J., \& Bus, A. G. (2010). Low-income immigrant pupils learning vocabulary through digital picture storybooks. Journal of Educational Psychology, 102(1), 54. 